Article

\title{
Exploring Efficiencies: Examining the Possibility of Decreasing the Size of the Briquettes Used as the Batch in the Electric Arc Furnace Dust Processing Line
}

\author{
Michał Bembenek (i) \\ AGH University of Science and Technology, Faculty of Mechanical Engineering and Robotics, Department of \\ Manufacturing Systems, 30-059 Kraków, Poland; bembenek@agh.edu.pl; Tel.: +48-12-617-31-20
}

Received: 8 July 2020; Accepted: 5 August 2020; Published: 8 August 2020

\begin{abstract}
Sintering of well-prepared briquetted mixtures in a shaft furnace is one of the possible methods of electric arc furnace dust (EAFD) utilization. Simultaneously, some metal oxides from exhaust gases can be separated. In this way, various metals are recovered, particularly zinc. As a result, zinc-free briquettes are produced with a high iron content, which can be used in the steelmaking process. This method is still being developed. In Ostrowiec Świetokrzyski, Poland, a prototype line of a new method for the reduction of zinc oxide in a shaft furnace with simultaneous sintering of briquettes was installed. The batch for the shaft furnace was actually briquetted in the roller press, which produces briquettes with a volume of $13 \mathrm{~cm}^{3}$. It may prove beneficial to reduce the size of the resulting briquettes, as a smaller size could prove more efficient in reducing zinc in the furnace. Decreasing the volume of the briquettes causes an increase in the power consumption in the drive system and brings an increase in the briquetting force, which occurred in the compaction zone. It could be harmful to the roller press construction. The aim of this article was to prove that decreasing the volume of briquettes of the EAFD mixtures had no negative effects on the roller press which was installed in the prototype line.
\end{abstract}

Keywords: EAFD processing; briquetting; EAFD briquette; zinc recovery; briquetting conditions

\section{Introduction}

One of the by-products of the steelmaking industry is electric arc furnace dust (EAFD) [1-4]. Due to containing some heavy metals (e.g., zinc, cadmium, copper, or lead) this kind of waste has been classified as hazardous [5-7]. Steel scrap, which is commonly delivered to steel mills, is largely coated with zinc, due to the fact that zinc is being used when galvanizing sheets for car production and other steel products like cans, fences, roofing, etc. [8,9]. It is estimated that about $50 \%$ of the world production of zinc is used for galvanizing steel components, which prolongs their life three- to fivefold. It can be assumed that the zinc content of the dust in steelmaking will constantly grow [10]. Dust from electric arc furnaces contains an average of $30-40 \%$ zinc and around $20 \%$ iron. During the production of each ton of steel in an electric arc furnace about 15-25 $\mathrm{kg}$ of EAFD is generated [11]. It is necessary to remove zinc from EAFD to recycle it properly [12-15]. Due to the high content of zinc in steelmaking dusts, new methods of dust removal were developed [16]. The method of EAF dust utilization consists of sintering of well-prepared briquetted mixtures in a shaft furnace and simultaneously separating metal oxides from the exhaust [17]. This method allows recovery of EAFD metals, particularly zinc. The $\mathrm{ZnO}$ in briquettes made of EAFD mixtures reacts with the carbon present in sinter, reduces to $\mathrm{Zn}$, and, due to high vapor pressure, evolves as gas and exits in the shaft gas phase. The zinc then oxidizes back to $\mathrm{ZnO}$ and is collected in the dedusting devices. As a result, zinc-free briquettes are produced with high iron content. These briquettes can then be used in steelmaking 
processes [18-21]. The prototype line of EAFD recovery was developed in Ostrowiec Świętokrzyski, Poland. In the line, a roller press is used. In the roller presses, the material is continuously compacted between two synchronous and counter-rotating rollers with cavities. The main advantages of a roller press for agglomeration of fine-grained materials are the continuous work with relatively low energy consumption, and the longer lifetime of the forming elements compared to other briquetters, e.g., screw or piston presses. At the moment, only those briquettes produced in the roller press with a volume of $13 \mathrm{~cm}^{3}$ are subjected to sintering [22]. The conditions of the sintering process need to be optimized. It is also necessary to check how the briquettes with smaller volumes will behave during sintering. Smaller briquettes obtain a larger outer surface area in relation to their bulk density. This can have a positive effect on the sintering process. However, it is required to do the calculations to check whether installing the forming rollers with a smaller forming cavity for producing briquettes of reduced volume will not adversely affect the operation of the roller press installed in the line [23]. Contrary to the roller mills [24] decreasing the volume of the briquettes can cause an increase in power consumption in the drive system, and entails raising the briquetting force taking place in the compaction zone $[25,26]$. This increased force can prove dangerous for the roller press construction. The aim of this article was to prove, based on laboratory tests and simulations, if the PW500 roller press installed in the EAFD recovery line (Figure 1) would not be overloaded after the installation of the rollers with a smaller volume of the briquettes. The PW500 roller press was equipped in the main motor drive with a $55 \mathrm{~kW}$ gearbox, which could slow down to 11.5 RPM rotation speed of the rollers, and a hydraulic system, which supported the unfixed roller with a force of $1000 \mathrm{kN}$ [27].

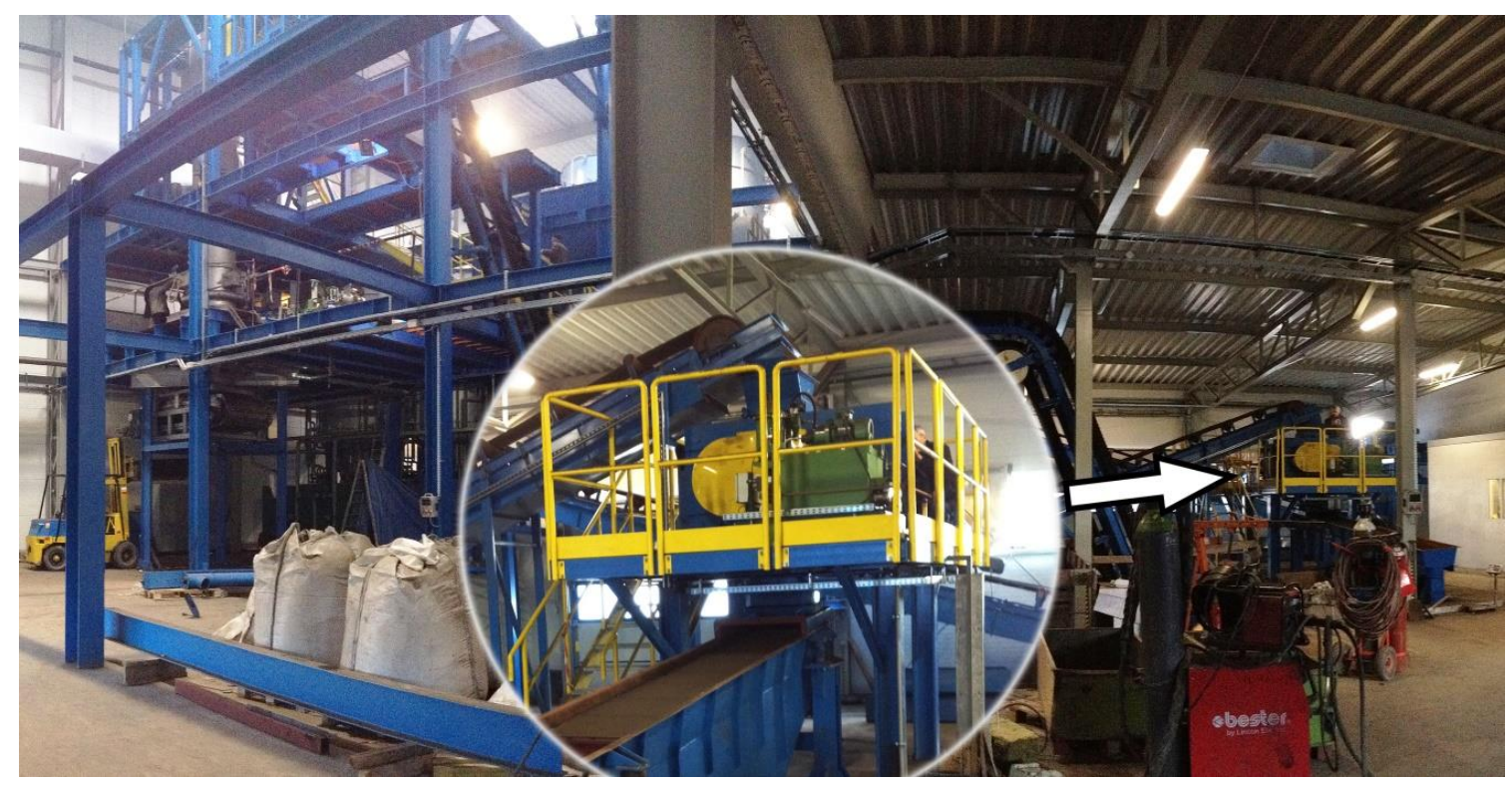

Figure 1. A view of the PW500 roller press installed in Ostrowiec Świętokrzyski, Poland.

\section{Materials and Methods}

To examine the loads occurring in the PW500 roller press after reducing the volume of cavities, a computer simulation program of a roller press was used. The simulator was developed by the employees of the Department of Manufacturing Systems of AGH University of Science and Technology, based on the Hryniewicz mathematical model of briquetting in a roller press [28]. The model used the thin layer method. This method consisted, in the separation in the compaction zone, of the volume elements of the briquetted material limited by the side surfaces of the rollers, their sealings, and two planes perpendicular to the direction of the material movement, distant from each other by an infinitely small $d y$ value. To determine the relationship between unit forces and stresses on the surface of a separated element, the equilibrium condition of the forces acting on it was used. The program allowed determination of the maximal unitary pressure value exerted on the briquettes in the central zone of the 
molding cavities, also loads caused in a drive and hydraulic system. When performing a simulation test of the briquetting process of a material, it was necessary to determine the material compaction pressure characteristic $(\vartheta)$ and the variability of friction static coefficient $\left(\mu_{\mathrm{s}}\right)$. In this case, the test of material compaction pressure characteristic $(\vartheta)$ and the variability of friction static coefficient $\left(\mu_{\mathrm{s}}\right)$ were performed, using a steelmaking EAFD from Rolled Products Division of Steelmaking Industry in Poland. The chemical composition of the dust was $\mathrm{Zn}(35 \%), \mathrm{Fe}(18 \%), \mathrm{Cl}(9 \%), \mathrm{Pb}(3 \%), \mathrm{Ca}(2.5 \%)$, $\mathrm{Si}(2 \%), \mathrm{Mn}(1.5 \%)$, and C (1\%) [17]. Coke breeze of grain size under $2.0 \mathrm{~mm}$ was used as a high carbon component. For the tests, mixtures were prepared which contained $47.7 \%$ of EAFD, 36.7\% scale, $7.3 \%$ fine coke breeze, $5.5 \% 80^{\circ} \mathrm{Bx}$ molasses, and $2.8 \%$ calcium hydroxide. The last two ingredients were a binder. Four mixtures were prepared, each with a different amount of water added, to obtain the appropriate moisture. The final moisture of the mixture was then chosen to be within the range of moisture favorable for briquetting of this process, resulting in a moisture in the briquetting material within $3.0 \%-6.3 \%$ [22]. Moisture was determined by the weight method at $105{ }^{\circ} \mathrm{C}$, until a constant weight was obtained. The Vibra AJH $420 \mathrm{CE}$ scale was used. The material compaction characteristic was determined using the ZDM-1 press equipped with a cylindrical close die with a $20 \mathrm{~mm}$ internal diameter. The force applied to the punch was continuously increased, up to $44 \mathrm{kN}$, which corresponded to the $140 \mathrm{MPa}$ compacting pressure. The punch feed rate was $6 \mathrm{~mm} / \mathrm{min}$. The punch displacement and the applied force was continuously measured and recorded using the data acquisition system. For each EAFD mixture, the measure was taken seven times. Measurements were averaged for each material moisture. Then, the compaction level was calculated by Equation (1)

$$
\mathrm{s}=\mathrm{H}_{\mathrm{p}} /\left(\mathrm{H}_{\mathrm{p}}-\mathrm{x}\right)
$$

where:

$\mathrm{s}$ is the compaction level,

$\mathrm{H}_{\mathrm{p}}$ is the initial height of the compacted material, and

$\mathrm{x}$ is the displacement of the punch.

Based on the measurements, the regression equation of the compaction pressure characteristic on compaction level and moisture was determined with Statistica, using the minimum squares method with a 95\% confidence level. It was also determined in the experiments that the minimum pressure necessary to properly consolidate EAFD mixtures could not be less than $25 \mathrm{MPa}$.

The variability of the external static friction coefficient between an EAFD mixture and the working surface of a roller was performed with laboratory stand STZ-1M (Figure 2). The EAFD mixture sample was a cylindrical briquette formed in a die with a $\emptyset 20 \mathrm{~mm}$ diameter and a height around $5 \mathrm{~mm}$. The $18 \mathrm{HGT}$ steel of hardness $55 \mathrm{HRC}$ was chosen as a pair sample. The STZ-1M consisted of two main components: the disc drive and the punch pressure system. The drive system achieved a rotation speed 10.5 RPM, corresponding to the linear velocity between the briquette and working rollers, $\mathrm{v}=0.0438 \mathrm{~m} / \mathrm{s}$ on the average $42 \mathrm{~mm}$ friction radius. The tests carried out for the pressure exerted on the briquette equaled 20, 40, 60, 80, 100, and $120 \mathrm{MPa}$, for the four mixtures. Each mixture was tested 7 times. While working on the results, 4 extreme samples were discarded, and the other ones were averaged for each EAFD mixture. 


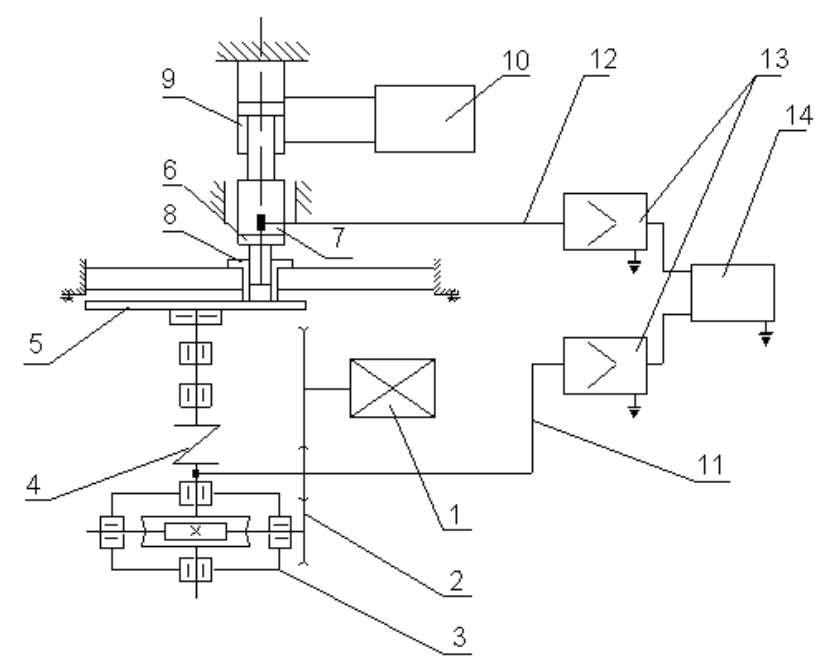

Figure 2. A scheme of the STZ-1M laboratory stand for testing friction in the briquetting process of fine-grained materials: 1-motor, 2-belt transmission, 3-belt gear, 4-clutch, 5-18HGT steel disc, 6-punch, 7-pressure transducer, 8-matrix, 9-hydraulic cylinder, 10-hydraulic system, 11-measuring path of the torque value, 12-measuring path of the pressure value, 13-amplifier, and 14-PC [29].

Based on the measurements, the regression equation of the variability of the friction coefficient on compaction level and moisture was determined with Statistica, using the minimum squares method with a $95 \%$ confidence level.

The grip angle was determined using the laboratory roller press with a $450 \mathrm{~mm}$ pitch diameter of the rollers. Rollers with cavities to obtain a saddle-shaped briquette with $6.5 \mathrm{~cm}^{3}$ volume and dimensions of $31 \times 30 \times 13 \mathrm{~mm}$ were installed. Briquetting tests of the EAFD mixtures with $3.0 \%, 5.0 \%$, and $6.8 \%$ moisture content were then performed. During the tests, a maximum briquetting pressure in the forming cavity was measured. It was realised by measuring the force acting on the $9 \mathrm{~mm}$ diameter pin installed in the bottom of the forming cavity. In the pressure measuring system, the pressure acting on the pin was transferred into the tensometric strain sensor, from which the measured signal was transmitted by NI DAQmx controllers in NI SCXI modular data acquisition kit to the NI_USB-6251 data acquisition module and PC. Data were recorded by LabView. The grip angle was determined in such a way that the results of the computer simulation and the average pressure measured in the roller press LPW450 during briquetting adjusted to the same value [30].

Originally installed in the PW500 roller press were rollers with a $500 \mathrm{~mm}$ pitch diameter and a $270 \mathrm{~mm}$ width, with the 294 cavities distributed in the 7 rows of 42 cavities each, allowing them to produce a saddle-shaped briquette with $13.0 \mathrm{~cm}^{3}$ volume and dimensions of $37 \times 37 \times 17 \mathrm{~mm}$ (Figure 3 ). A new set of rollers with a smaller cavity volume was designed in SolidWorks. The diameter and the width of the rollers were not changed. Decreasing of cavity volume caused change in the rows and cavity numbers. The parameters of the redesigned roller ring are presented in Table 1. 


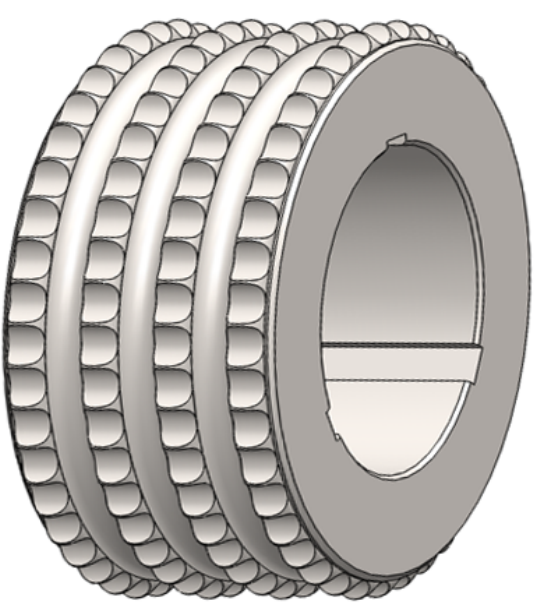

(a)

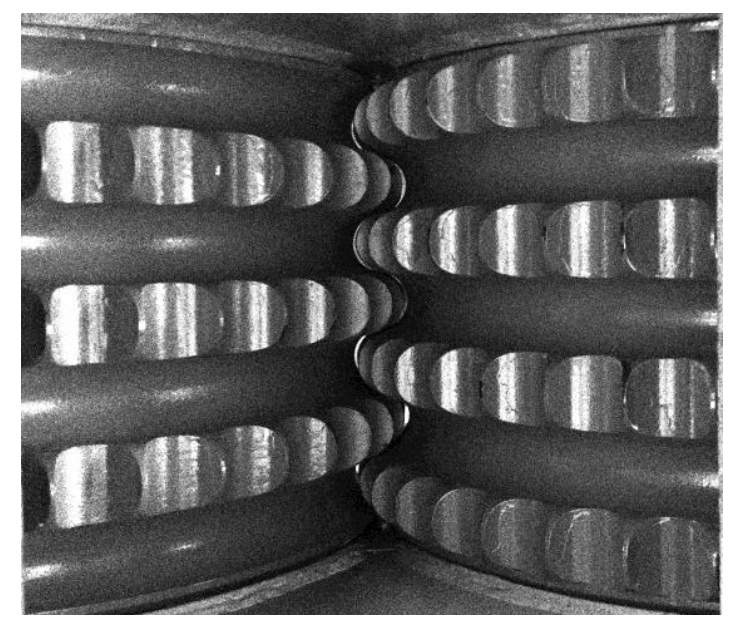

(b)

Figure 3. The working rollers originally installed in the roller press PW500, (a) model created in the SolidWorks program and (b) the view down to compaction unit.

Table 1. The parameters of the rollers designed with reduced volume of the cavities.

\begin{tabular}{ccccc}
\hline $\begin{array}{c}\text { Briquette Volume } \\
\left(\mathbf{c m}^{\mathbf{3}}\right)\end{array}$ & $\begin{array}{c}\text { Briquette Size } \\
(\mathbf{m m})\end{array}$ & $\begin{array}{c}\text { Number of } \\
\text { Rows }\end{array}$ & $\begin{array}{c}\text { Number of Cavities } \\
\text { in the Row }\end{array}$ & $\begin{array}{c}\text { Total Number of } \\
\text { Cavities }\end{array}$ \\
\hline 13.0 & $37 \times 37 \times 17$ & 7 & 42 & 294 \\
10.5 & $34 \times 34 \times 16$ & 7 & 45 & 315 \\
8.5 & $32 \times 32 \times 15$ & 8 & 48 & 384 \\
6.5 & $30 \times 29 \times 14$ & 9 & 52 & 468 \\
\hline
\end{tabular}

\section{Results and Discussion}

The moisture for the EAFD mixtures for compaction pressure characteristic $(\vartheta)$ and variability of friction coefficient $\left(\mu_{\mathrm{s}}\right)$ were $2.5 \%, 3.5 \%, 4.5 \%$, and $5.5 \%$. The results of compaction level tests are shown in Figure 4. All the compaction pressure characteristics were progressive. It confirmed that EAFD mixtures were adequate for consolidation in a roller press. For briquetting pressures over $25 \mathrm{MPa}$, all the characteristic were linear. It corresponded with the minimal pressure to obtain a solid briquette. The lowest compaction level was obtained for the EAFD mixture with $2.5 \%$ moisture content. The obtained cylindrical briquettes from that mixture in the tests were the most brittle compared to the rest. The highest compaction level was the $4.5 \%$ moisture content EAFD mixture. The difference between the lowest and highest compaction level rose with the increase in briquetting pressure. The highest difference was noticed for the $140 \mathrm{MPa}$ pressure, amounting to $19.7 \%$.

The regression equation of compaction characteristics on compaction level and moisture describes Equation (2)

$$
\vartheta=7.785508 \mathrm{~s}^{4.304809} \mathrm{w}^{-0.939358}
$$

where:

$\vartheta$ is the compaction pressure characteristic,

$\mathrm{s}$ is the compaction level, and

$\mathrm{w}$ is the moisture content. 


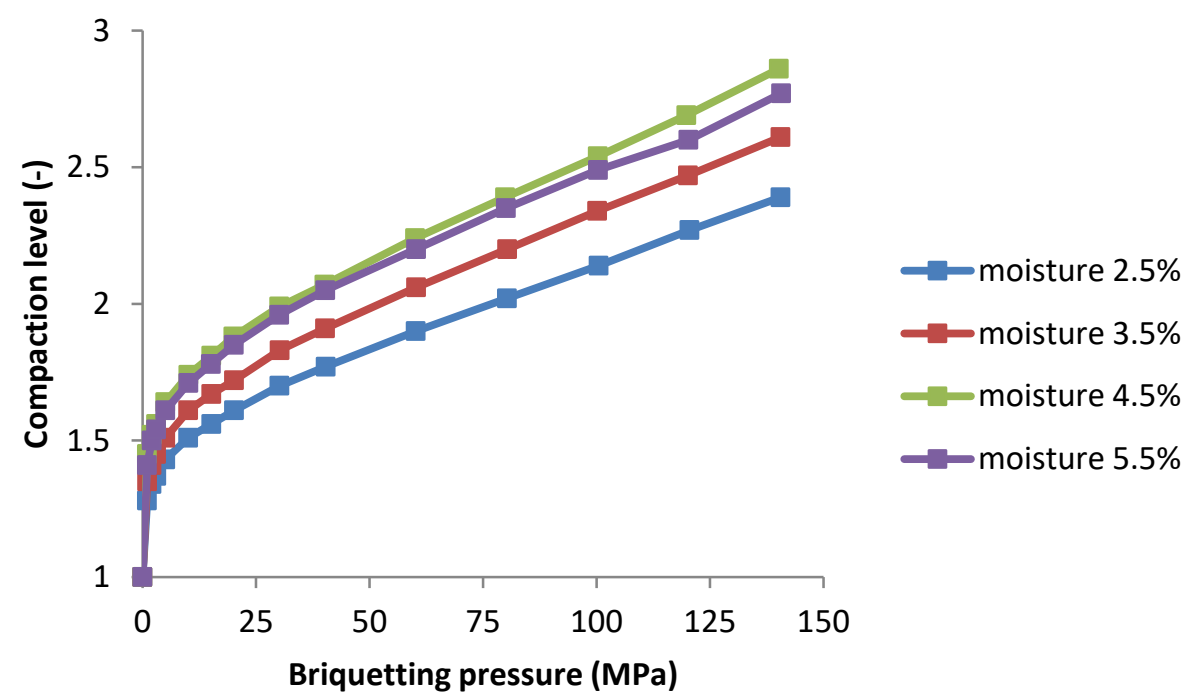

Figure 4. The compaction level with the briquetting pressure for electric arc furnace dust (EAFD) mixtures of different moisture contents.

The example course of friction force in time obtained in the STZ-1 stand for the EAFD mixture is shown in Figure 5. The calculated results of the variability of the friction coefficient tests is shown in Figure 6. Analyzing the characteristics, it could be seen that in each case, the coefficient of external static friction decreased with an increase in briquetting pressure. The EAFD mixture with $2.5 \%$ moisture content was characterized significantly different from the others, because it had the highest friction coefficient for each briquetting pressure. The EAFD mixture with $4.5 \%$ moisture content had a higher external friction coefficient than the 3.5\% mixture. However, with increasing briquetting pressure, the characteristics intersected at $40 \mathrm{MPa}$, and then the highest value was the $3.5 \%$ moisture content mixture. The EAFD mixture with 5.5\% moisture content, among the tested mixtures, was characterized by the lowest values of the friction coefficient.

The regression equation of the variability of friction coefficient on compaction level and moisture describes Equation (3)

$$
\mu_{\mathrm{s}}=-0.525828 \mathrm{~s}-0.001754 \mathrm{w}+1.501769
$$

where:

$\mu_{\mathrm{s}}$ is the coefficient of static friction,

$\mathrm{s}$ is the compaction level, and

$\mathrm{w}$ is the moisture content.

The example of briquetting pressure characteristics in the forming cavity is presented in Figure 7. The value of the maximum measured briquetting pressure decreased with increases in the moisture content. In Table 2, the value of the grip angle is presented. Based on the results, the average $5.16^{\circ}$ grip angle was determined and used in the simulation for the PW500 press. For the simulation $2.0^{\circ}$, the elastic expansion angle was used [30]. The maximum power consumption was calculated based on no changes in the drive system and a constant roller rotation speed at 11.5 RPM. The calculation was based on $90 \%$ efficiently of the drive system. 


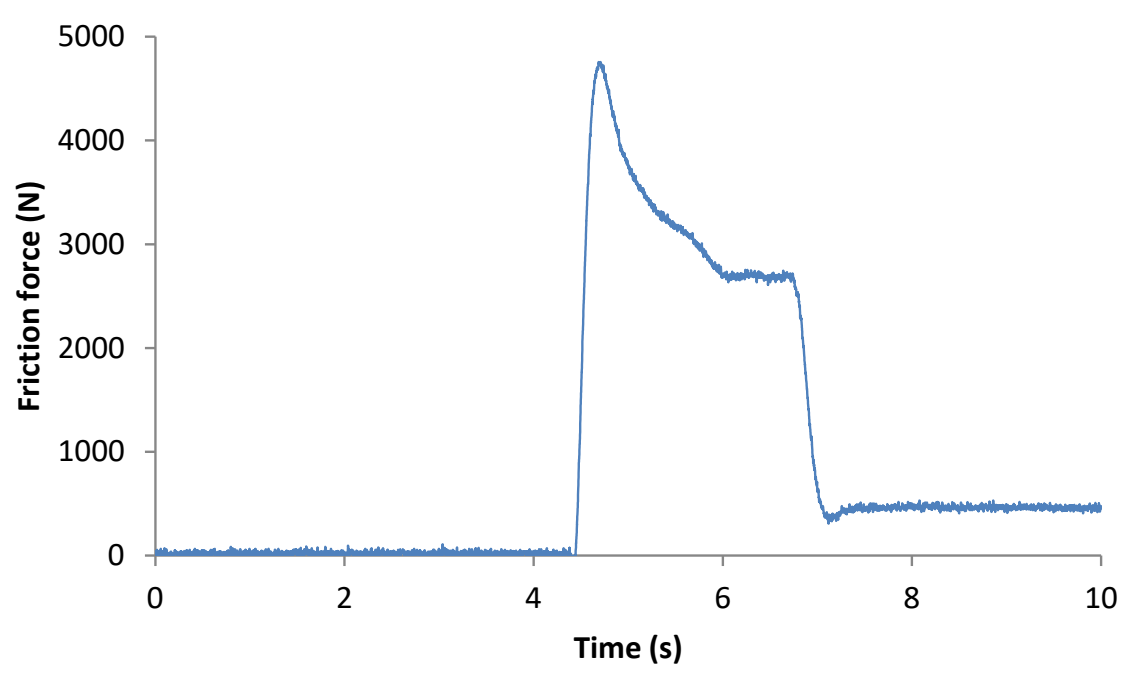

Figure 5. The course of friction force in time for the EAFD mixture with $2.5 \%$ moisture content under the $20 \mathrm{MPa}$ pressure obtained in STZ-1 stand.

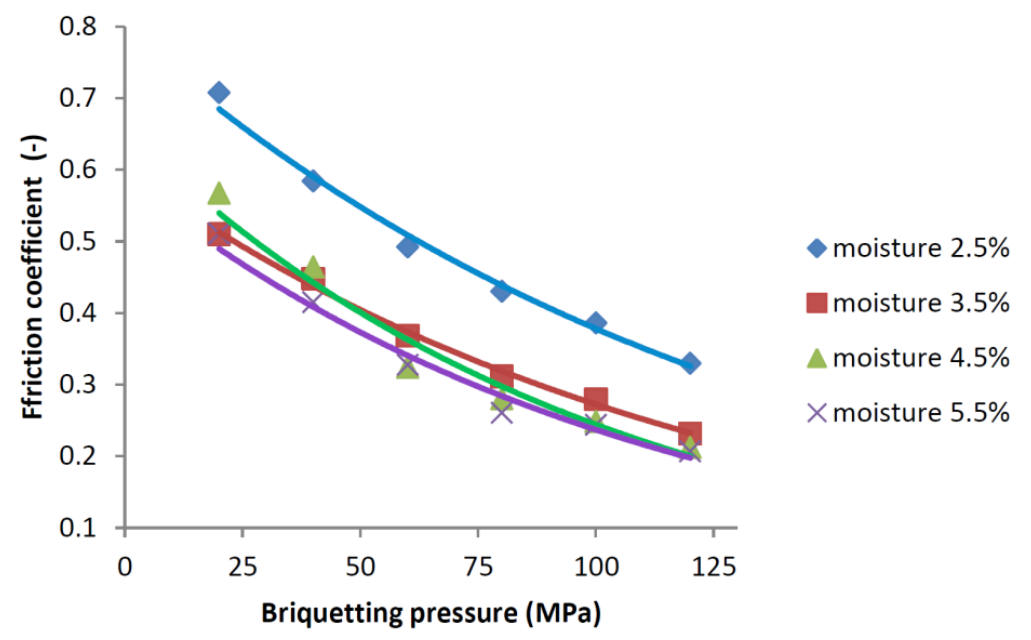

Figure 6. The friction coefficient with the briquetting pressure for EAFD mixtures of different moisture contents.

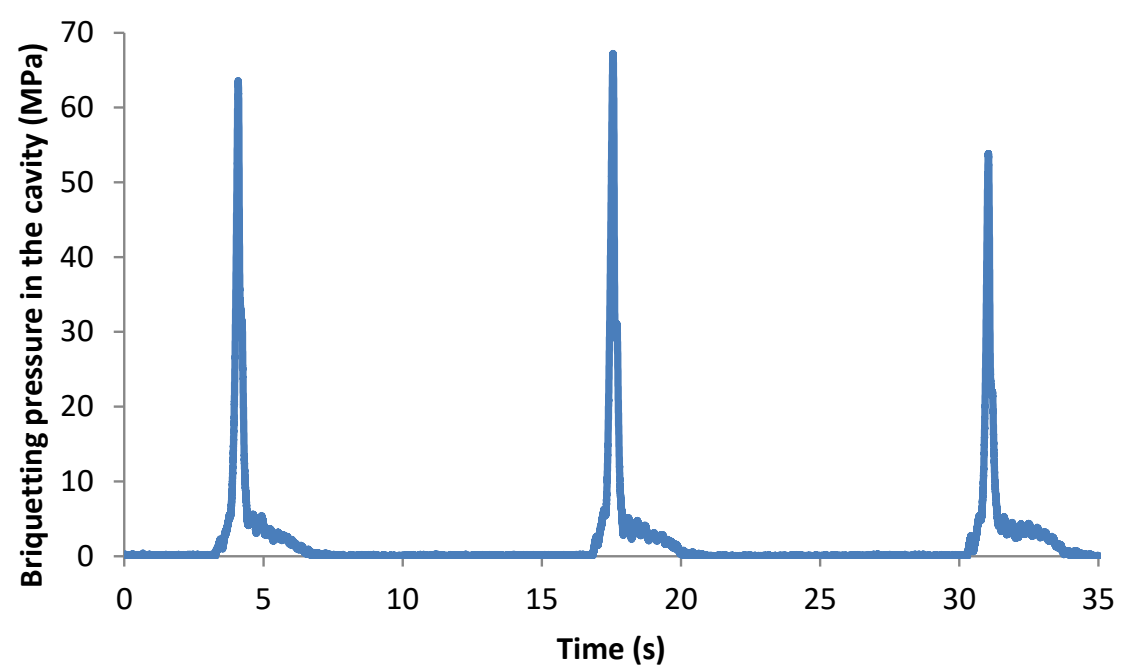

Figure 7. The course of unit pressure in the forming cavity during briquetting of the EAFD mixture with $5 \%$ moisture content. 
Table 2. The measured maximum briquetting pressure in the cavity and calculated grip angle.

\begin{tabular}{cccc}
\hline $\begin{array}{c}\text { Moisture Content of } \\
\text { EAFD Mixture (\%) }\end{array}$ & $\begin{array}{c}\text { Maximum Measured } \\
\text { Briquetting Pressure } \\
\mathbf{( M P a )}\end{array}$ & $\begin{array}{c}\text { Average Maximum } \\
\text { Measured Unit Pressure } \\
\mathbf{( M P a )}\end{array}$ & Grip Angle $\left(^{\circ}\right.$ ) \\
\hline 3.0 & $73.1,78.3,67.9$ & 73.1 & 4.82 \\
5.0 & $63.4,66.6,53.0$ & 61.0 & 5.29 \\
6.8 & $51.9,52.4,39.6$ & 48.0 & 5.36 \\
\hline
\end{tabular}

Based on the results presented in Table 3, it could be concluded that the PW500 roller press was correctly selected for EAFD mixture briquetting in the EAFD recovery line. The simulation indicated that maximal value of the pressure in the forming cavity decreased with increasing EAFD mixture moisture. The roller press equipped with the standard rollers (with cavity volume of $13 \mathrm{~cm}^{3}$ ) under normal conditions of use (for EAFD mixes with a moisture content in the range of $3.0 \%-6.3 \%$ ) had a power surplus of $57 \%$, taking into account the installed $55 \mathrm{~kW}$ motor drive. However, such a large power surplus resulted from the fact that it is a pilot line and also intended for large-scale experiments. Drying the EAFD mixture down to a value of $2 \%$ resulted in an increase of maximum pressure, force, torque, and power. The same resulted from a reduction of the gap between rollers. As predicted, reducing the volume of briquettes increased energy demand and the force exerted between the rollers.

Table 3. The results of simulations on decreasing the cavities in the PW500 roller press.

\begin{tabular}{|c|c|c|c|c|c|c|}
\hline $\begin{array}{l}\text { Briquette } \\
\text { Volume }\end{array}$ & $\begin{array}{l}\text { EAFD Mixture } \\
\text { Moisture (\%) }\end{array}$ & $\begin{array}{l}\text { Gap Between } \\
\text { Rollers (mm) }\end{array}$ & $\begin{array}{l}\text { Maximum } \\
\text { Pressure } \\
\text { (MPa) }\end{array}$ & $\begin{array}{l}\text { Maximum } \\
\text { Force }(\mathbf{k N})\end{array}$ & $\begin{array}{l}\text { Maximum } \\
\text { Torque } \\
\text { (Nm) }\end{array}$ & $\begin{array}{c}\text { Maximum Power } \\
\text { Consumption } \\
(\mathbf{k W})^{*}\end{array}$ \\
\hline 13.0 & 3.0 & 2 & 46.9 & 226.7 & 14785 & 19.7 \\
\hline 13.0 & 2.0 & 2 & 68.4 & 330.4 & 21506 & 28.7 \\
\hline 13.0 & 3.0 & 1 & 57.1 & 275.7 & 17807 & 23.7 \\
\hline 13.0 & 2.0 & 1 & 83.2 & 401.6 & 25891 & 34.5 \\
\hline 13.0 & 4.5 & 2 & 32.3 & 155.9 & 10195 & 13.6 \\
\hline 13.0 & 6.3 & 2 & 23.7 & 114.6 & 7514 & 10.0 \\
\hline 10.5 & 3.0 & 2 & 60.4 & 292.9 & 18869 & 25.2 \\
\hline 10.5 & 2.0 & 2 & 88.0 & 425.7 & 27430 & 36.6 \\
\hline 10.5 & 3.0 & 1 & 76.7 & 370.7 & 23631 & 31.5 \\
\hline 10.5 & 2.0 & 1 & 111.7 & 539.6 & 34331 & 45.8 \\
\hline 8.5 & 3.0 & 2 & 61.9 & 299.3 & 19301 & 25.7 \\
\hline 8.5 & 2.0 & 2 & 90.1 & 435.8 & 28057 & 37.4 \\
\hline 8.5 & 3.0 & 1 & 78.9 & 381.2 & 24268 & 32.4 \\
\hline 8.5 & 2.0 & 1 & 114.8 & 554.8 & 35254 & 47.0 \\
\hline 6.5 & 3.0 & 2 & 70.2 & 339.8 & 21793 & 29.1 \\
\hline 6.5 & 2.0 & 2 & 102.1 & 494.7 & 31669 & 42.2 \\
\hline 6.5 & 3.0 & 1 & 91.7 & 443.3 & 28014 & 37.4 \\
\hline 6.5 & 2.0 & 1 & 133.4 & 644.9 & 40680 & 54.2 \\
\hline
\end{tabular}

* assumed $90 \%$ propulsion system efficiency.

\section{Conclusions}

This article presented an analysis of reducing the PW500 roller press briquette volume. The briquetting machine was installed in an EAFD utilization line. The line consisted of sintering of well-prepared briquetted mixtures in a shaft furnace and simultaneously separating metal oxides from the exhaust. This method allowed recovery of EAFD metals, particularly zinc. Smaller briquettes obtained a larger outer surface area in relation to their bulk density. This reduction in briquette size could have a positive effect on the sintering process.

The PW500 roller press simulation of the maximum pressure, force, torque, and power during the briquetting process was conducted. They showed that the PW500 roller press was correctly selected for the pilot line. The simulation results showed that, for normal roller press conditions (EAFD mixture moisture content in the range of $3.0 \%-6.3 \%$ ), it was possible to reduce the size of the briquettes 
down to a volume of $6.5 \mathrm{~cm}^{3}$. In all the simulations carried out, their results were lower than $55 \mathrm{~kW}$ (installed in the press motor drive power) and $1000 \mathrm{kN}$ (force of the hydraulic system supports the unfixed rollers). However, for a reduced briquette volume down to $6.5 \mathrm{~cm}^{3}$, long-term operation of the briquetting machine with a small gap between the rollers $(1 \mathrm{~mm})$ and in conditions of over-dried EAFD mixture (down to $2 \%$ ) could be dangerous for the press. According to the results obtained in the simulation, the roller press worked then with practically the maximum possible energy demand of $54.2 \mathrm{~kW}$. This might result in the overheating of the drive system. An interesting direction of the future research may also be the determination of the impact of briquette porosity on the sintering process. The obtained results may also be useful for determining the parameters of the roller press to obtain briquettes of higher porosity.

Funding: The article was funded by Subsidy grant number 16.16.130.942/KSW.

Acknowledgments: I would like to thank Piotr Englart and Tomasz Tomża for their help during the research.

Conflicts of Interest: The author declares no conflict of interest.

\section{References}

1. Suetens, T.; Van Acker, K.; Blanpain, B.; Mishra, B.; Apelian, D. Moving Towards Better Recycling Options for electric arc furnace dust. J. Mater. 2014, 66, 1119-1121.

2. Joulazadeh, M.; Joulazadeh, F. Slag; Value added steel industry byproducts. Arch. Metall. Mater. 2010, 55, 1137-1145. [CrossRef]

3. Gara, P.; Zwolińska, B. Model of converter dusts and iron-bearing slurries management in briquetting. Metalurgija 2016, 55, 515-518.

4. Jursová, S. Metallurgical waste and possibilities of its processing. In Proceedings of the 19th International Conference on Metallurgy and Materials: Metal 2010, Ostrava, Czech Republic, 18-20 May 2010; pp. 115-120.

5. Rosler, G.; Pichler, C.; Antrekowitsch, J.; Wegscheider, S. "2sDR": Process development of a sustainable way to recycle steel mill dusts in the 21st century. J. Min. Met. Mater. Soc. 2014, 66, 1721-1729. [CrossRef]

6. Kashiwaya, Y.; Tsubone, A.; Ishii, K.; Sasamoto, H. Thermodynamic analysis on the dust generation from EAF for the recycling of dust. ISIJ Int. 2004, 44, 1774-1779. [CrossRef]

7. Buzin, P.; Heck, N.; Vilela, A. EAF dust: An overview on the influences of physical, chemical and mineral features in its recycling and waste incorporation routes. J. Mater. Res. Technol. 2016, 6, 194-202. [CrossRef]

8. Shawabkeh, R.A. Hydrometallurgical extraction of zinc from Jordanian electric arc furnace dust. Hydrometallurgy 2010, 104, 61-65. [CrossRef]

9. Besta, P.; Samolejová, A.; Janovská, K.; Lenort, R.; Haverland, J. The effect of harmful elements in production of iron in relation to input and output material balance. Metalurgija 2012, 51, 325-328.

10. Gawenda, T.; Saramak, D. Assessment of the process efficiency for metallurgical zinc waste screening in vibrating screen. J. Pol. Miner. Eng. Soc. 2018, 19, 189-194. (In Polish) [CrossRef]

11. Guezennec, A.-G.; Huber, J.-C.; Patisson, F.; Sessiecq, P.; Birat, J.-P.; Ablitzer, D. Dust formation in Electric Arc Furnace: Birth of the particles. Powder Technol. 2005, 157, 2-11. [CrossRef]

12. Havlık, T.; Vidor, E.; Souza, B.; Bernardes, A.M.; Homrich Schneider, I.A.; Miskufova, A. Hydrometallurgical processing of carbon steel EAF dust. J. Hazard. Mater. 2006, 135, 311-318. [CrossRef] [PubMed]

13. Kumar, D.S.; Sah, R.; Sekhar, V.R.; Vishwanath, S.C. Development and use of mill scale briquettes in BOF. Ironmak. Steelmak. 2017, 44, 134-139. [CrossRef]

14. El-Hussiny, N.A.; Shalabi, M.E.H. A self-reduced intermediate product from iron and steel plants waste materials using a briquetting process. Powder Technol. 2011, 205, 217-223. [CrossRef]

15. Lopez, F.A.; Lopez-Delgado, A. Enhancement of electric arc furnace dust by recycling to electric arc furnace. J. Environ. Eng. 2002, 128, 1169-1174. [CrossRef]

16. Cholewiński, W.; Kenig, R.; Pasierb, J.; Woźniacki, Z.; Hryniewicz, M.; Bembenek, M.; Gara, P. Method for the Recovery and Separation of Zinc Oxide in the Pyrometallurgical Process of Agglomeration of Fine Grained Waste Materials, Preferably Metallurgical Discards. Polish Patent PL 225,632 B1, 23 September 2016. (In Polish). 
17. Magdziarz, A.; Kuźnia, M.; Bembenek, M.; Gara, P.; Hryniewicz, M. Briquetting of EAF dust for its utilisation in metallurgical processes. Chem. Process Eng. 2015, 36, 263-271. [CrossRef]

18. Babanin, V.I.; Eremin, A.Y. Briquetting fine-grained materials in ferroalloys production: Practical experience and future prospects. Metallurgist 2006, 50, 241-247. [CrossRef]

19. Hryniewicz, M.; Janewicz, A. Research into the possibility of basic oxygen furnace consolidation in a roll press. Pol. J. Environ. Stud. 2008, 17, 235-239.

20. Lemos, L.; Seabra da Rocha, S.H.F.; Andrade de Castro, L.F. Reduction disintegration mechanism of cold briquettes from blast furnace dust and sludge. J. Mater. Sci. Technol. 2015, 4, 278-282. [CrossRef]

21. Mihok, L.; Baricova, D. Recycling of oxygen converter flue dust into oxygen converter charge. Metalurgija 2003, 42, 271-275.

22. Bembenek, M. Research and prospects for new areas of using roller presses. Przem. Chem. 2017, 9, $1845-1847$. (In Polish) [CrossRef]

23. Drzymła, Z. Research into the briquetting process for improved design of briquetting machines. Mater. Des. 1994, 15, 33-40. [CrossRef]

24. Tomporowski, A.; Flizikowski, J.; Kruszelnicka, W. A new concept of roller-plate mill. Przem. Chem. 2017, 96, 1750-1755. (In Polish) [CrossRef]

25. Yehia, K.A. Estimation of roll press design parameters based on the assessment of a particular nip region. Powder Technol. 2007, 177, 148-153. [CrossRef]

26. Baiul, K.V. Synthesis of Roller Press Rational Design for Composite Solid Fuel Production. Probl. Reg. Energetics 2019, 2, 103-116. [CrossRef]

27. Hryniewicz, M.; Bembenek, M.; Janewicz, A.; Kosturkiewicz, B. Agglomeration of fine-grained materials in roll presses with asymmetrical compaction unit. Przem. Chem. 2015, 94, 2223-2226. (In Polish) [CrossRef]

28. Hryniewicz, M. Method of Selection of Roll Presses and Elaboration of Design Criteria for Their Modernization or Construction; Wydawnictwa AGH: Kraków, Poland, 1997. (In Polish)

29. Hryniewicz, M.; Janewicz, A.; Kosturkiewicz, B. Research of external friction in briquetting process of copper concentrates. Inżynieria I Apar. Chem. 2006, 45, 68-69. (In Polish)

30. Bembenek, M. The issue of selection: Shape and volume of briquettes agglomerated in a roller press. J. KONES Powertrain Transp. 2017, 24, 31-38. [CrossRef] 